\title{
ELSEVIER_JFUE_8212
}

\section{Effects of direct injection timing of ethanol fuel on engine knock and lean burn in a port injection gasoline engine}

Yuan Zhuang

Yuan.Zhuang-1@student.uts.edu.au

Guang Hong*

guang.hong@uts.edu.au

School of Electrical, Mechanical and Mechatronic Systems, Faculty of Engineering and Information Technology, University of Technology, Sydney, Australia

${ }^{*}$ Corresponding author. Address: PO Box 123, NSW 2007, Australia. Tel.: +61 0295142678.

\section{Abstract}

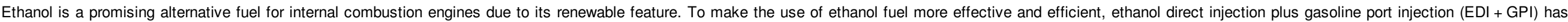

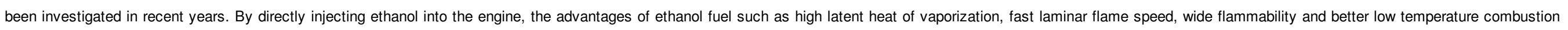

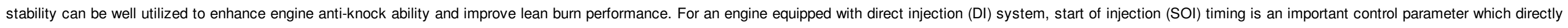

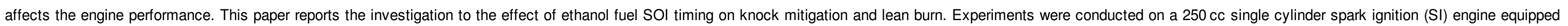

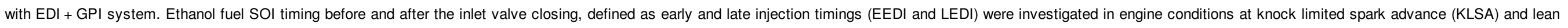

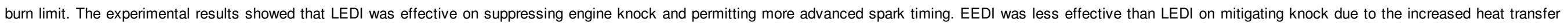

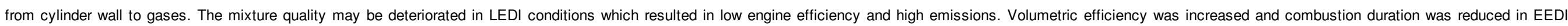

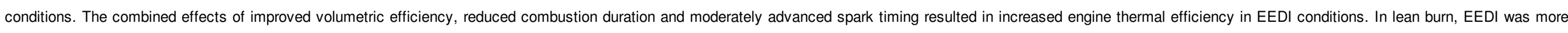

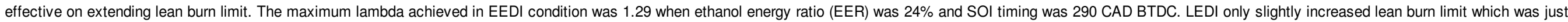

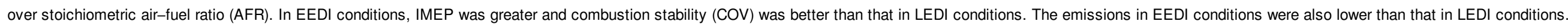

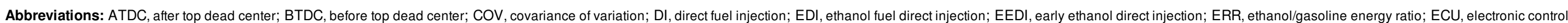

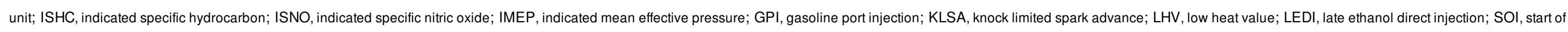
injection; HE, heating energy; HC, hydrocarbon; MBT, maximum brake torque; NO, nitric oxygen; PFI, port fuel injection; Lambda ( $\lambda$ ), airffuel equivalence ratio

Keywords: EDI, GPF; Ethanol direct injection; Gasoline port injection; Fuel injection timing; Engine knock; Lean burn

\section{Introduction}

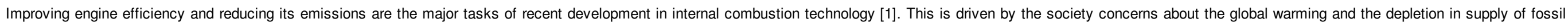

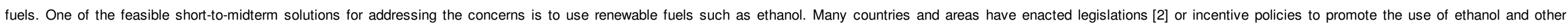

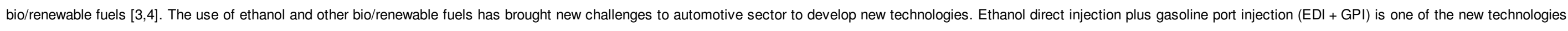
in recent development.

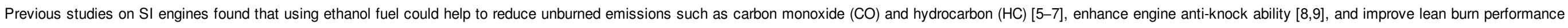

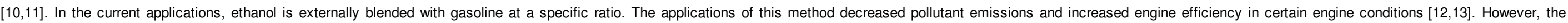

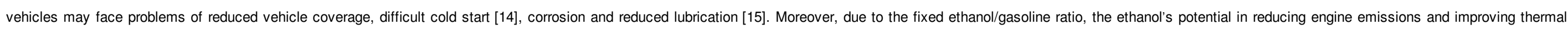

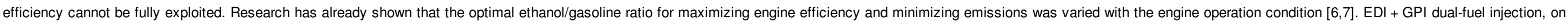

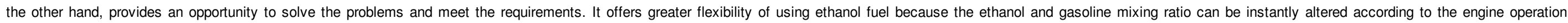




\section{ELSEVIER_JFUE_8212}

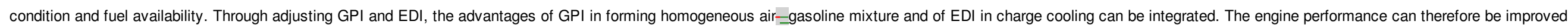

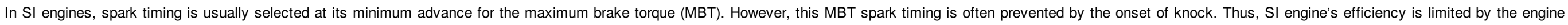

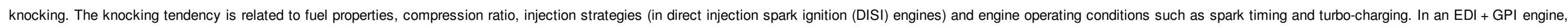

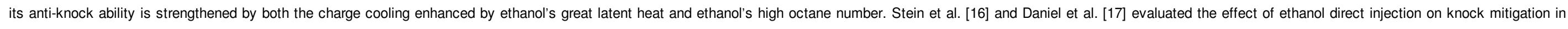

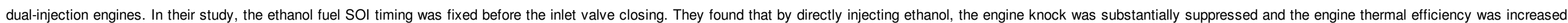

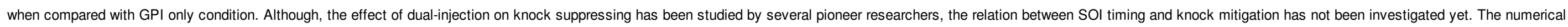

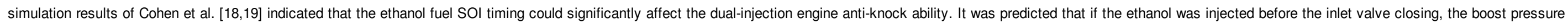

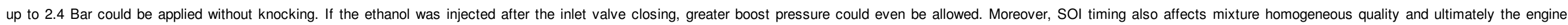
efficiency and emissions. Thus, finding the relation between SOI timing and engine knock, efficiency and emissions is necessary in EDI + GPI engine development.

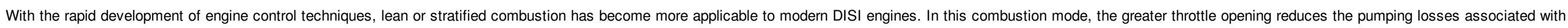

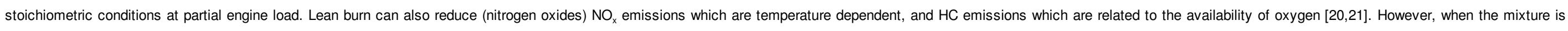

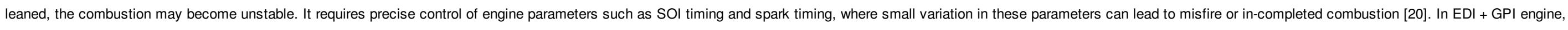

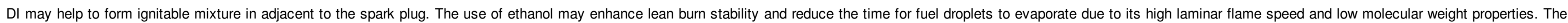

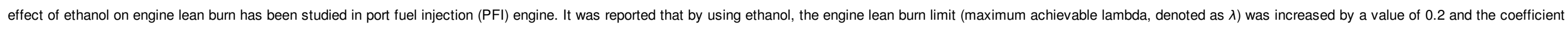
of variation (COV) of IMEP was reduced by about 2\% [22,23]. As a new technology, the study on lean burn in dual-injection engine has not been reported so far and therefore requires investigation.

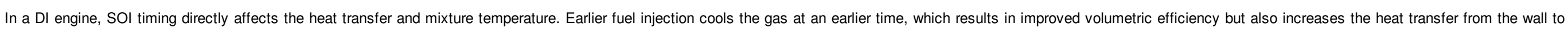

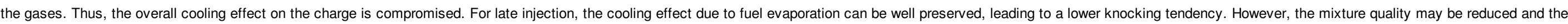

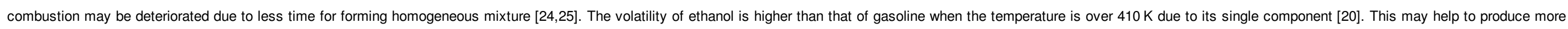
homogeneous mixture and reduce the time for fuel evaporation in DISI engine. Therefore, the SOI timing for ethanol fuel can be retarded to enhance anti-knock ability while maintaining the high quality of the mixture [26,27].

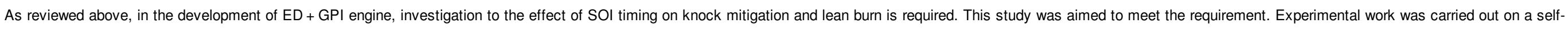
developed EDI + GPI engine. The results presented and discussed include effects of ethanol fuel SOI timing on KLSA, lean burn limit, combustion and emissions.

\section{Experimental apparatus}

\subsection{Test engine and instrumentation}

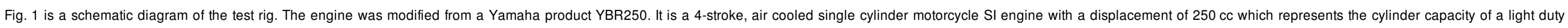

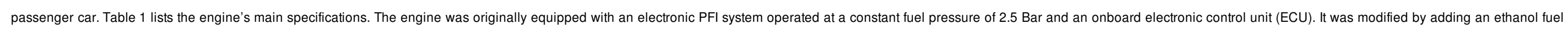

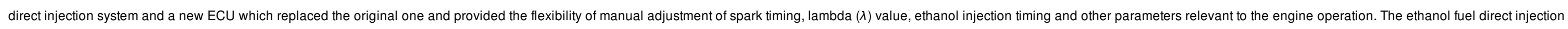

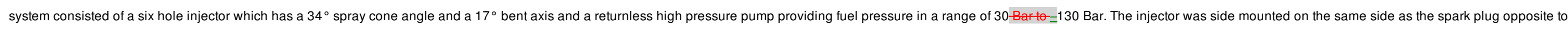

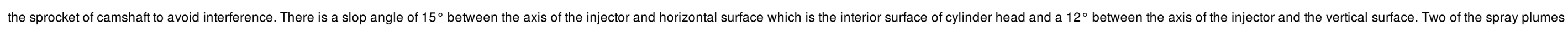

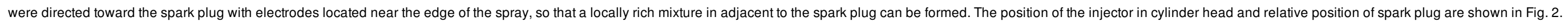




\section{ELSEVIER_JFUE_8212}

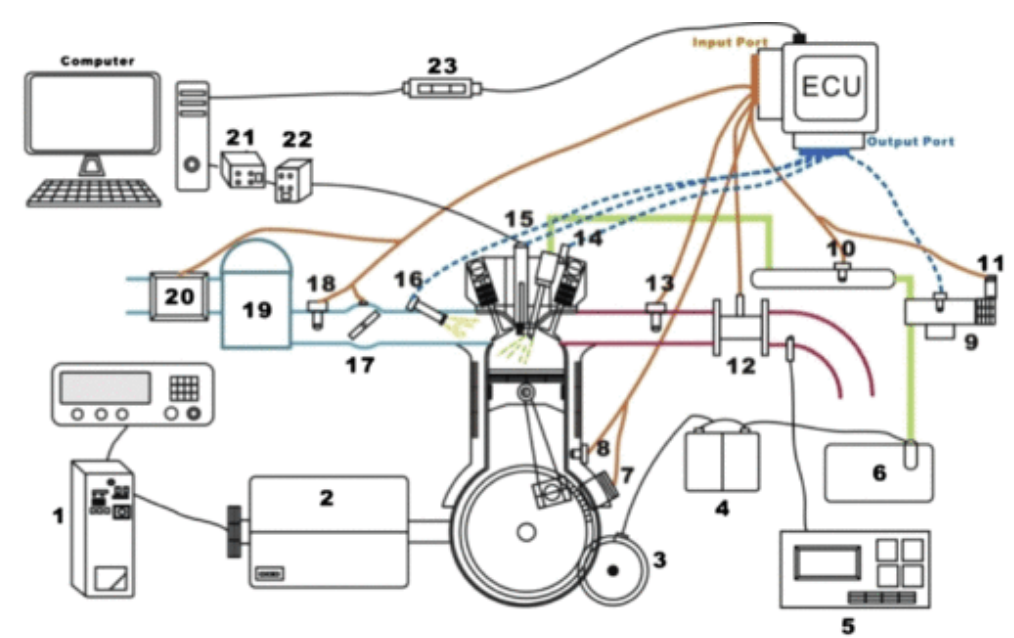

1. Dynamometer controller 2. Dynamometer 3. Start motor 4. Battery 5. Horiba MXEA-584L gas analyzer 6 . Ethanol fuel tank 7. Encoder on crankshaft 8 . Temperature sensor 9 . High pressure fuel pump 10. Common rail pressure sensor 11. Encoder on high pressure pump shaft 12. Bosch wide-band lambda sensor 13. Temperature Sensor 14. Direct fuel injector 15. Kistler spark plug pressure transducer 16 . Port fuel injector 17 . Throttle valve position sensor and driving motor 18. Temperature sensor 19. Inlet air regulator 20. Air flow meter 21. Combustion analyzer 22. Charge amplifier 23. CAN Communication module

Fig. 1 Schematic of the engine system.

\section{Table 1 Engine specifications}

Engine type

Displacement

Bore $\times$ stroke

Compression ratio

Intake valve timing

Exhaust valve timing

\section{Single cylinder, air cooled}

4-stroke, SOHC

\section{$249.0 \mathrm{~cm}^{3}$}

$74.0 \mathrm{~mm} \times 58.0 \mathrm{~mm}$

$9.80: 1$

Opening: $45^{\circ}$ BTDC

Closing: $60^{\circ} \mathrm{ABDC}$

Opening: $87^{\circ}$ ATDC

Closing: $21^{\circ}$ ATDC 


\section{ELSEVIER_JFUE_8212}

\subsection{Experimental procedures}

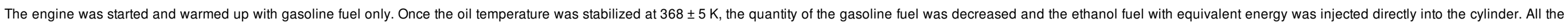

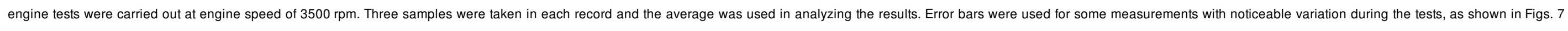
(volumetric efficiency) and 13 (lean burn limit) to show the variance.

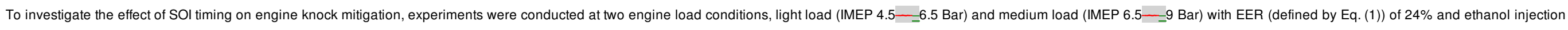

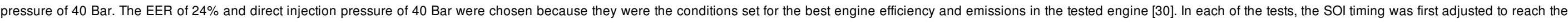

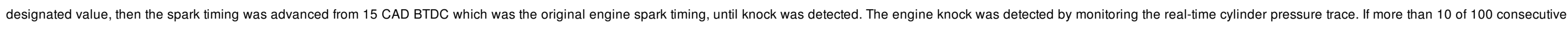

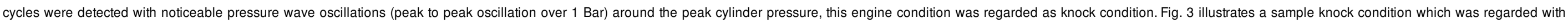

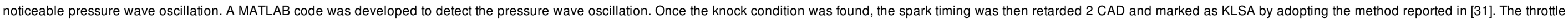
position was fixed during each of the tests and AFR was kept at stoichiometric by adjusting the injection pulse-widths for gasoline and ethanol at each EER.

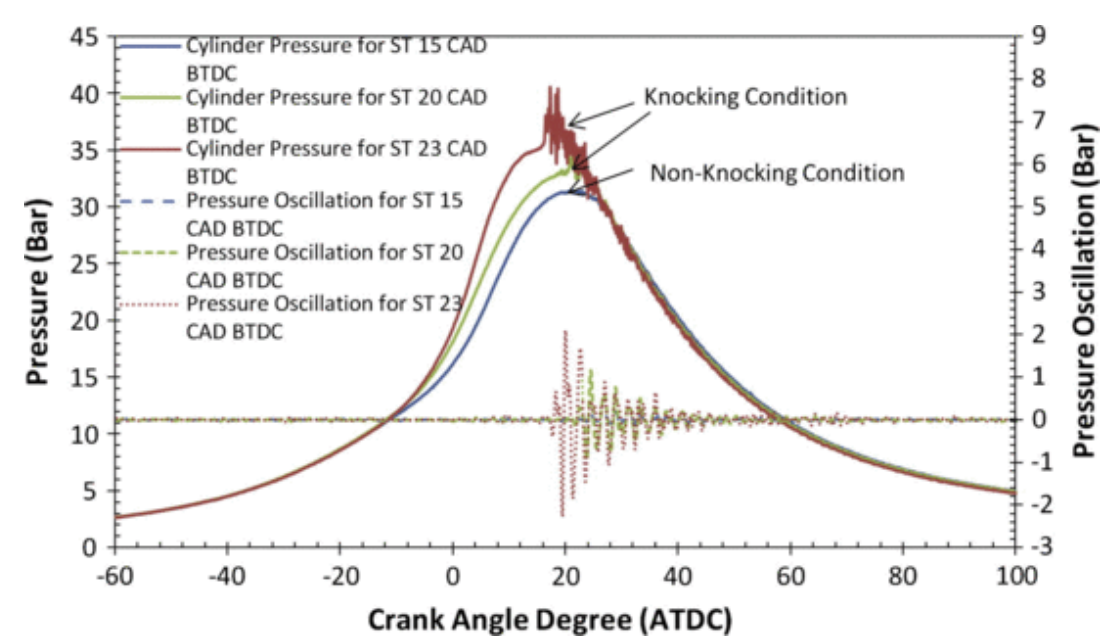

Fig. 3 Original cylinder pressure trace and 3-20 kHz band pass filtered pressure for knocking and non-knocking conditions at different Spark Timing (ST) $(3500 \mathrm{rpm}$, throttle =30\% and gasoline fuel only)

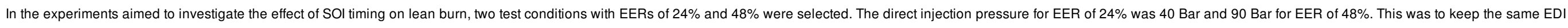

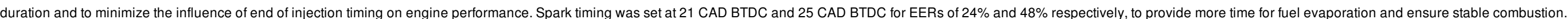

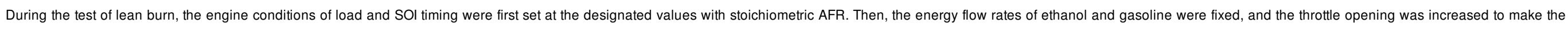

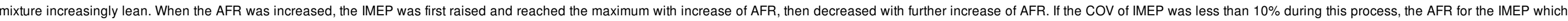

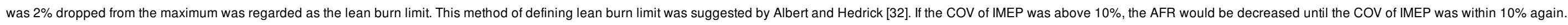

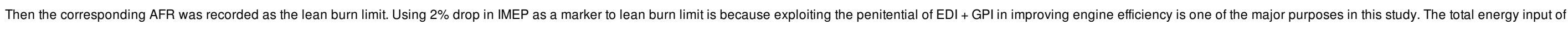

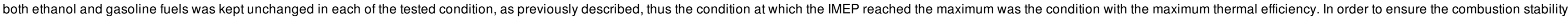

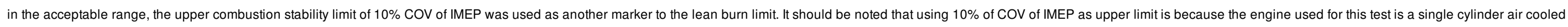
engine with a relatively short stroke of $58 \mathrm{~mm}$. Previous studies on similar small engines also used the $10 \%$ of COV of IMEP as the acceptance [33].

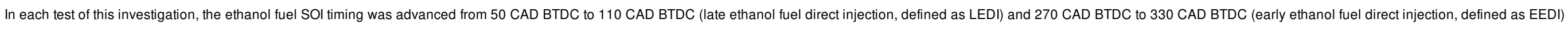

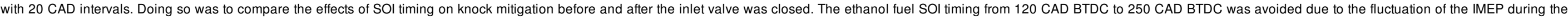

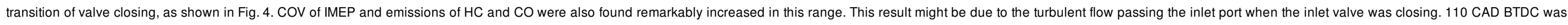




\section{ELSEVIER_JFUE_8212}

selected as the initial timing for LEDI, because the inlet valve was closed at 120 CAD BTDC. 50 CAD BTDC was chosen as the end point of LEDI to give minimum sufficient time for ethanol fuel to vaporize before the ignition.

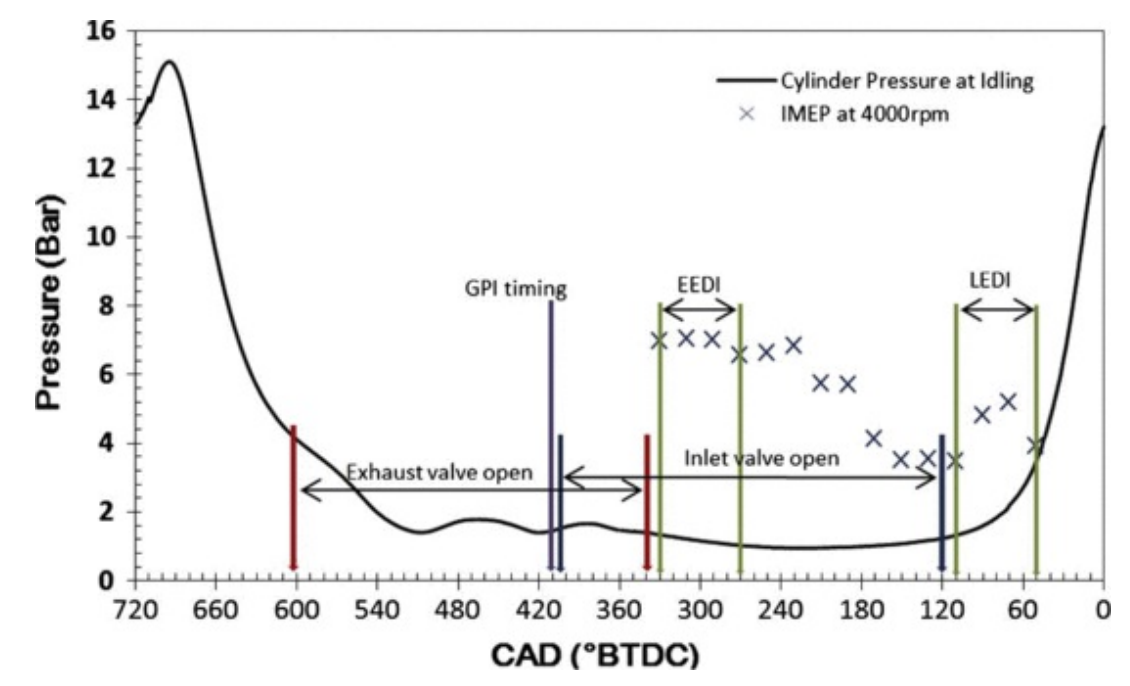

Fig. 4 Experimental engine SOI timing windows.

The EER is described in Eq. (1).

Ethanol/gasoline energy ratio (EER)

$=\grave{H} E_{\mathrm{E} \text { thanol }} /\left(\dot{H} E_{\mathrm{E}}\right.$ thanol $\left.+\dot{H} E_{\text {Gasoline }}\right)$

where $(\dot{H} E$, rate of heating energy, $\mathrm{kJ} / \mathrm{s})=$ fuel mass flow rate $(\mathrm{g} / \mathrm{s}) \times \mathrm{LHV}$. The denominator in Eq. $(1)$ is the rate of the total heating energy of the two fuels.

\section{Results and discussion}

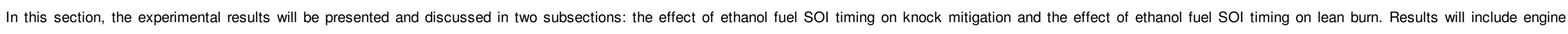
performance, combustion and emissions.

\subsection{Effect of SOI timing on knock mitigation}

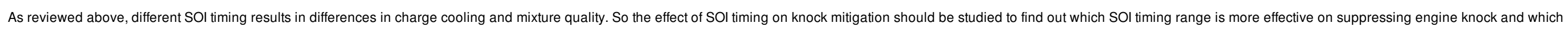

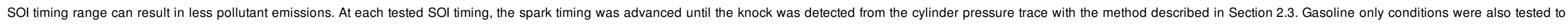
provide the reference frame for comparison.

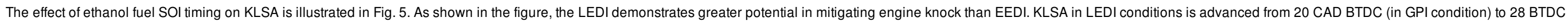

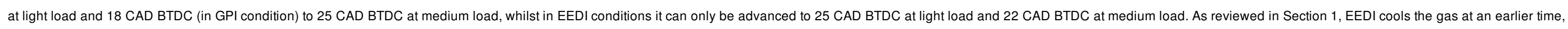

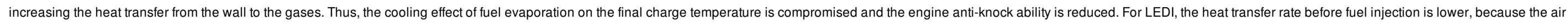

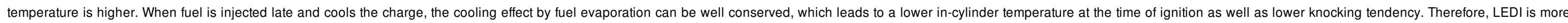

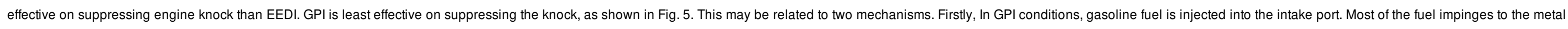

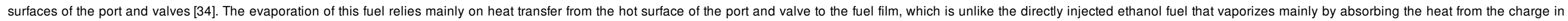
cylinder. Therefore, the evaporation of the gasoline fuel in GPI condition cools the charge less effectively than that in EDI conditions. Secondly, gasoline's latent heat of vaporization and octane number are lower than ethanol's. 


\section{ELSEVIER_JFUE_8212}

\section{EEDI Injection Timing (CAD BTDC)}

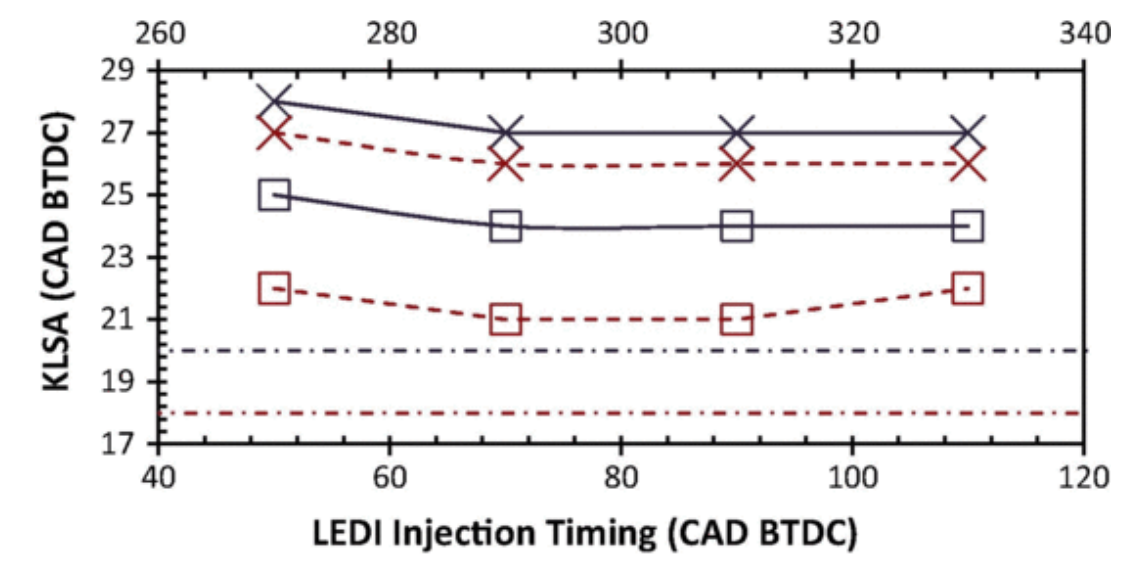

$\longrightarrow$ L Light Load LEDI

- - $\nless$ - - Medium Load LEDI

-. . - . Light Load GPI

- - - - Medium Load EEDI

-... - Medium Load GPI

Fig. 5 Variation of KLSA with SOI timing.

$\square$ Light Load EEDI

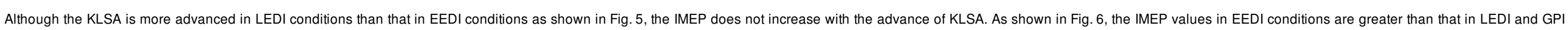

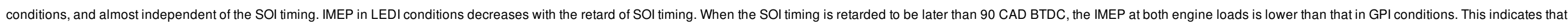

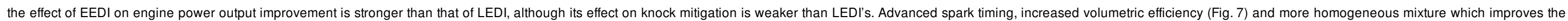
combustion (Figs. 8 and 9) may contribute to the increase of IMEP in EEDI conditions. Among these factors, the mixture quality improved in EEDI conditions may play an important role in increasing the IMEP.

EEDI Injection Timing (CAD BTDC)

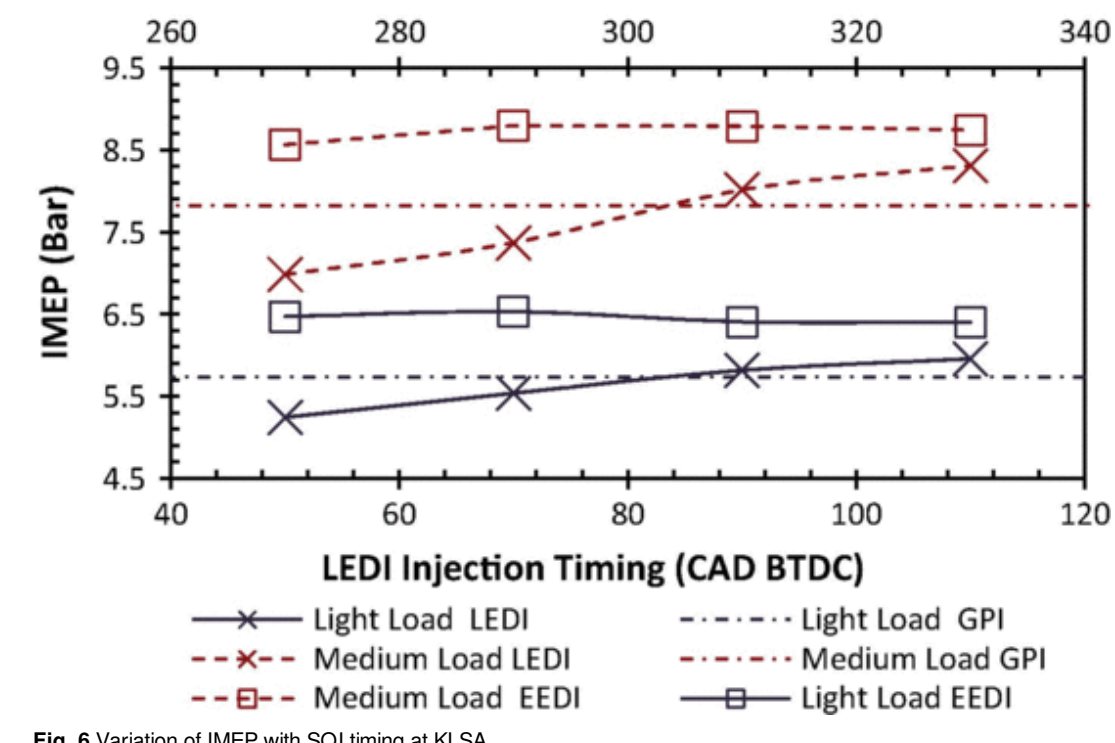

Fig. 6 Variation of IMEP with SOI timing at KLSA. 


\section{ELSEVIER_JFUE_8212}

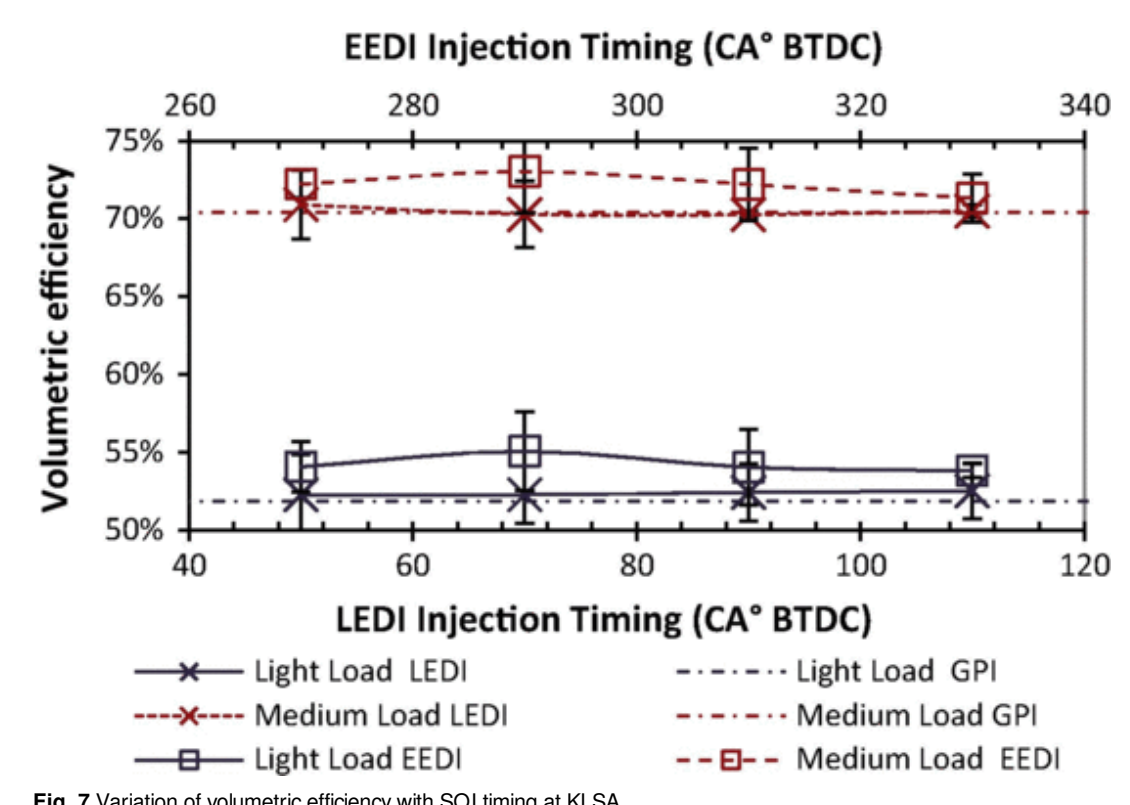

Fig. 7 Variation of volumetric efficiency with SOI timing at KLSA.

\section{EEDI Injection Timing (CAD BTDC)}

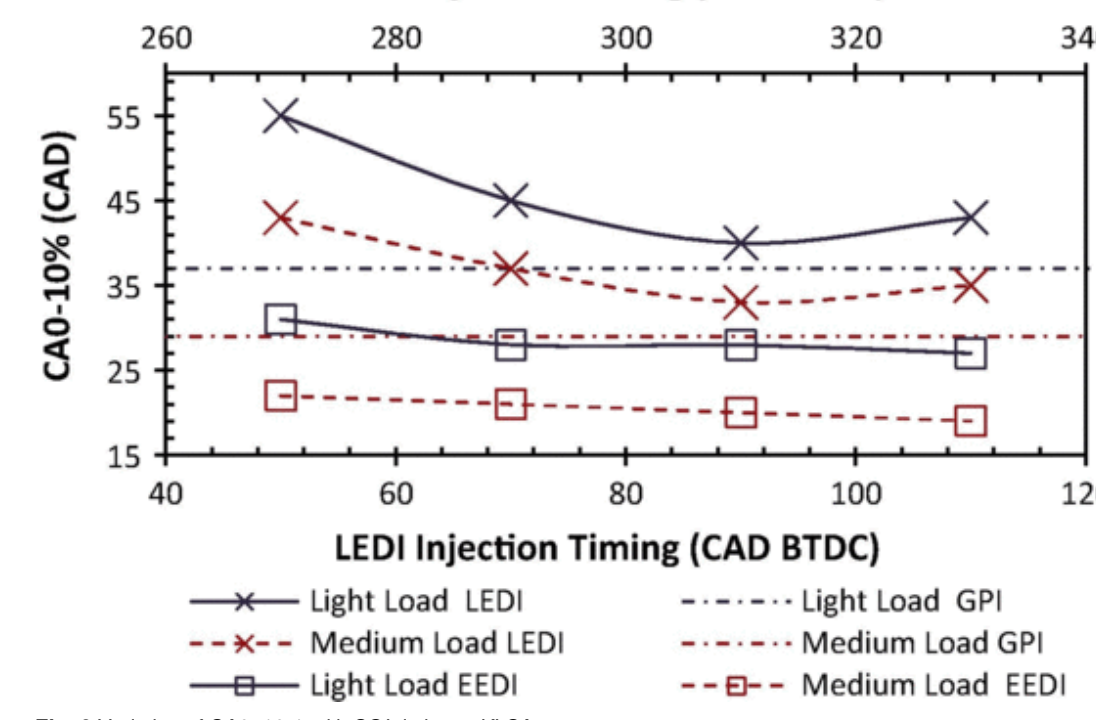

Fig. 8 Variation of $\mathrm{CA} 0-10 \%$ with SOI timing at KLSA. 


\section{ELSEVIER_JFUE_8212}

\section{EEDI Injection Timing (CAD BTDC)}

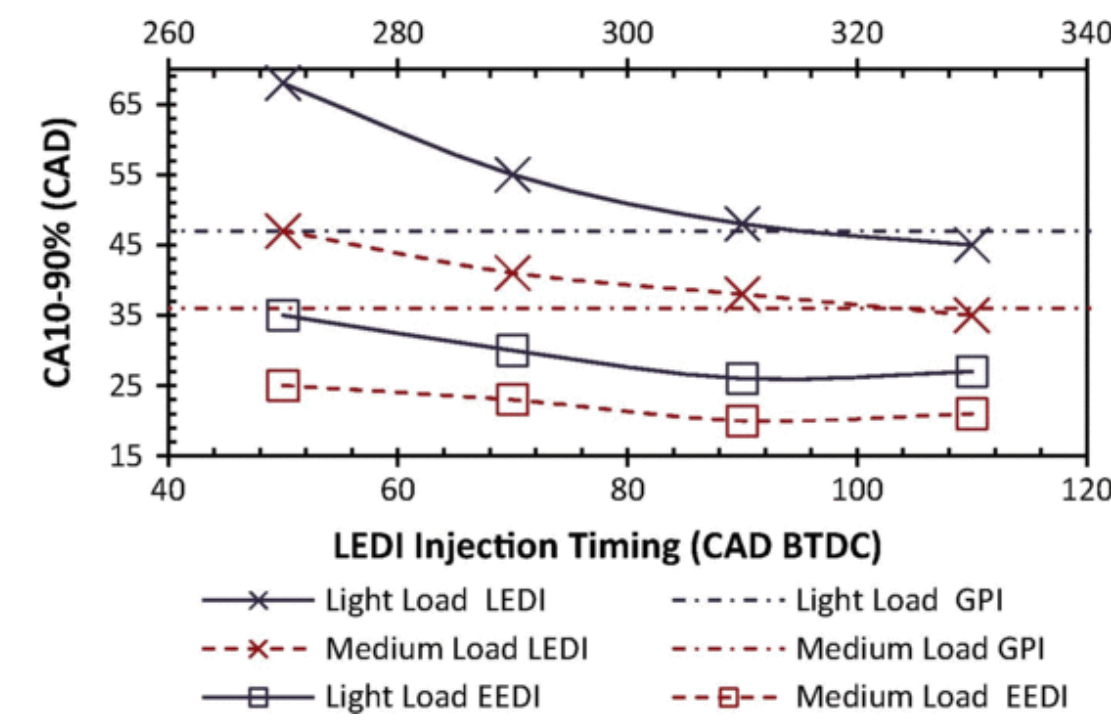

Fig. 9 Variation of CA10-90\% with SOI timing at KLSA.

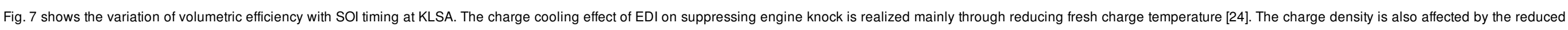

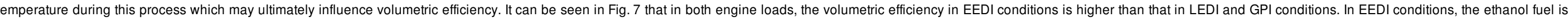

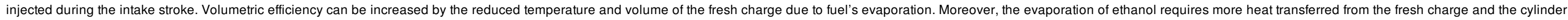
wall than evaporation of gasoline does. Thus the charge temperature can be further reduced, resulting higher volumetric efficiency in EEDI condition.

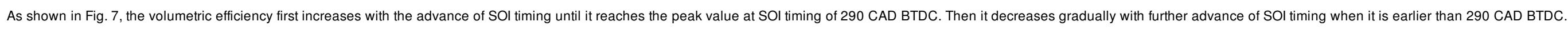

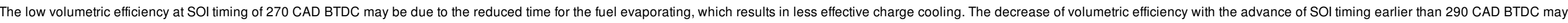

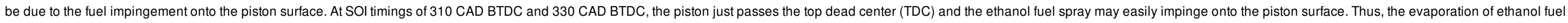
may mainly take the heat away from the piston surface and cylinder wall rather than from the fresh charge. The volumetric efficiency decreases subsequently.

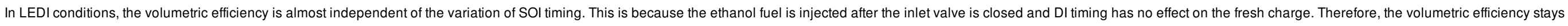

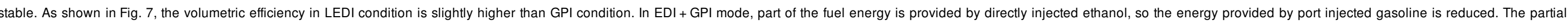

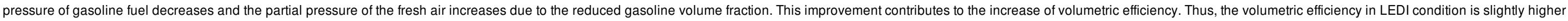
than that in GPI condition.

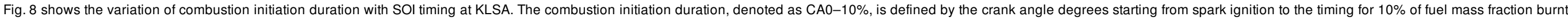

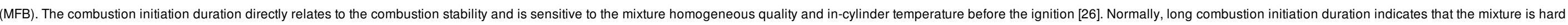

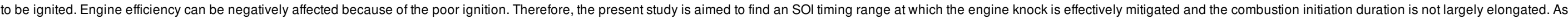

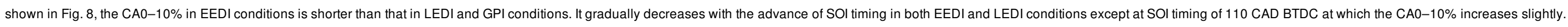

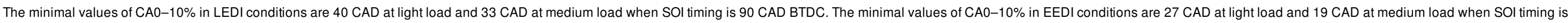

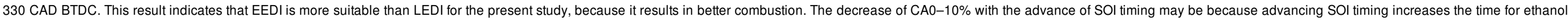

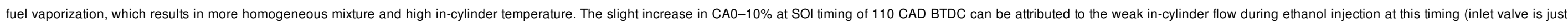
open), which decreases the mixture homogeneous quality and prolongs the combustion initiation duration. 


\section{ELSEVIER_JFUE_8212}

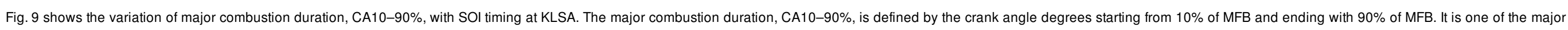

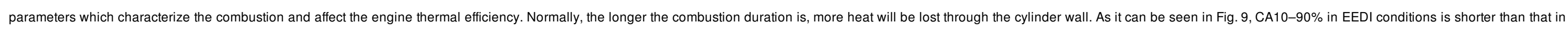

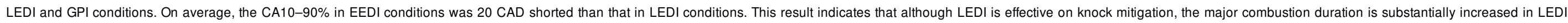

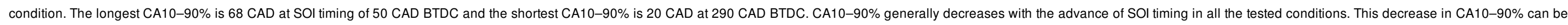

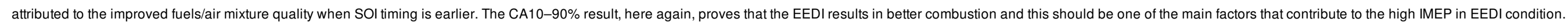

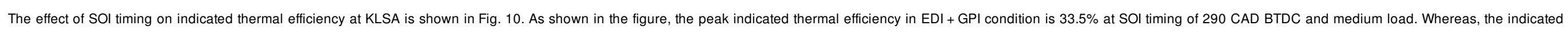

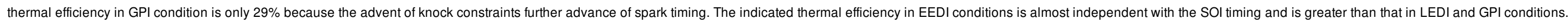

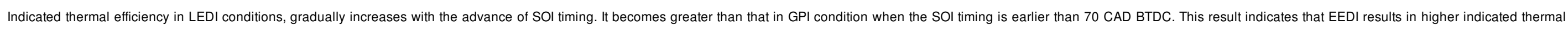

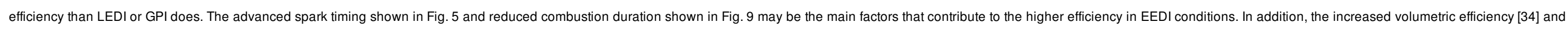
ethanol's high energy content of stoichiometric mixture per unit mass of air [35] may also contribute to the increase of indicated thermal efficiency.

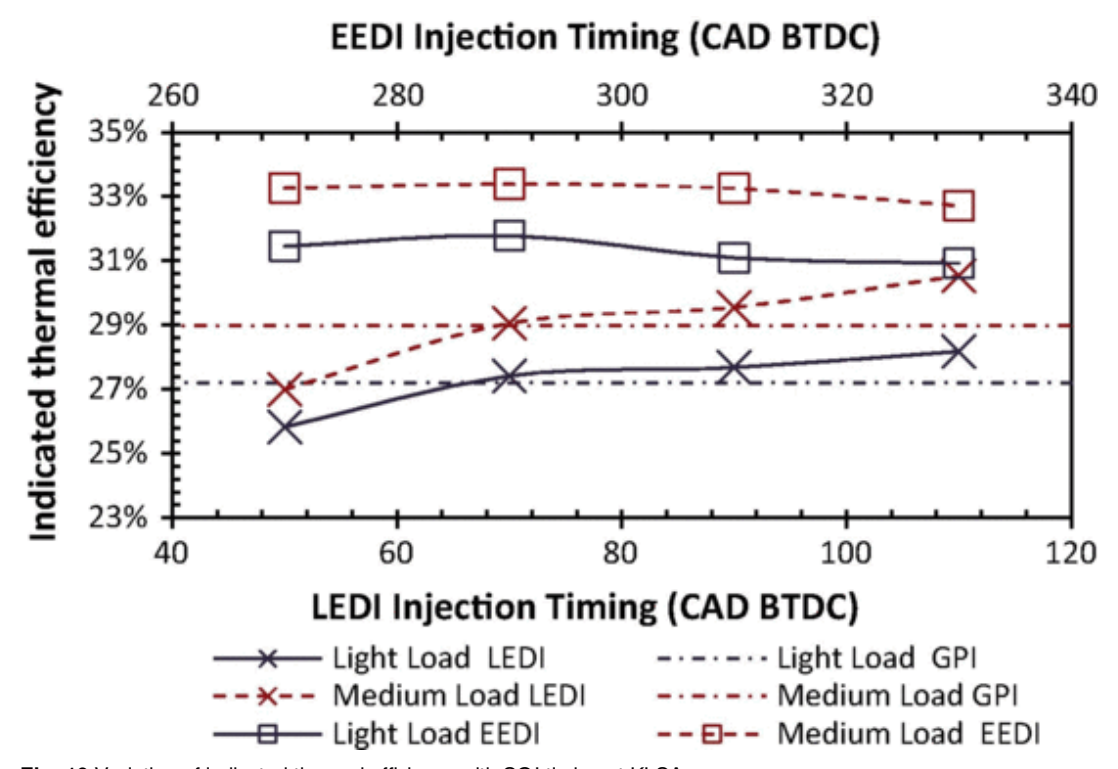

Fig. 10 Variation of indicated thermal efficiency with SOI timing at KLSA.

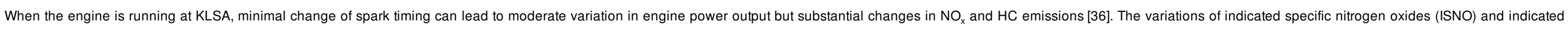

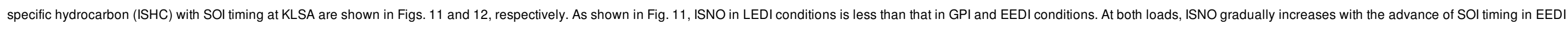
and LEDI conditions. 


\section{ELSEVIER_JFUE_8212}

increased and NO emissions increase as well.

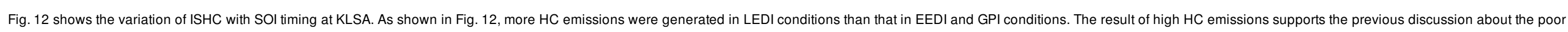

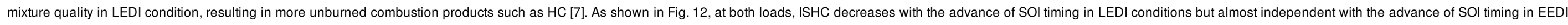

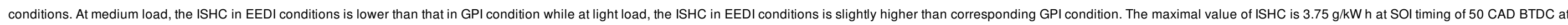

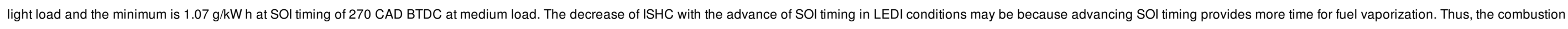
is more complete and ISHC decreases.

\subsection{Effect of injection timing on lean combustion}

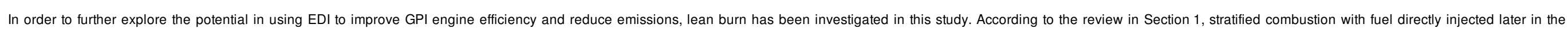

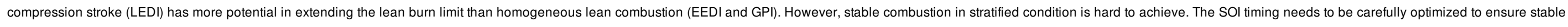

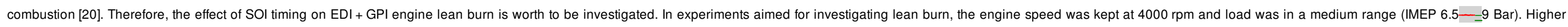
engine speed and load conditions may lead to unstable engine operation in lean burn as found by Küsell et al. [37]. Conditions with EERs of $24 \%$ and $48 \%$ were tested. GPI condition was also tested to provide comparison.

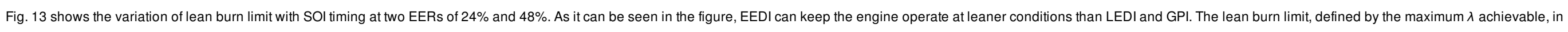

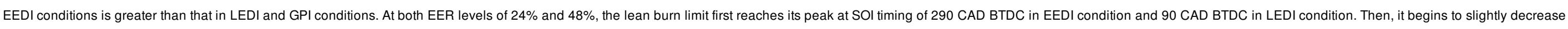

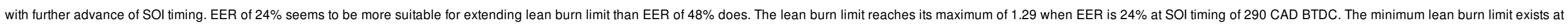
EER of $48 \%$ in LEDI conditions, which is only slightly greater than the stoichiometric AFR $(\lambda=1)$ while the other lean burn limits are all above $\lambda=1.1$.

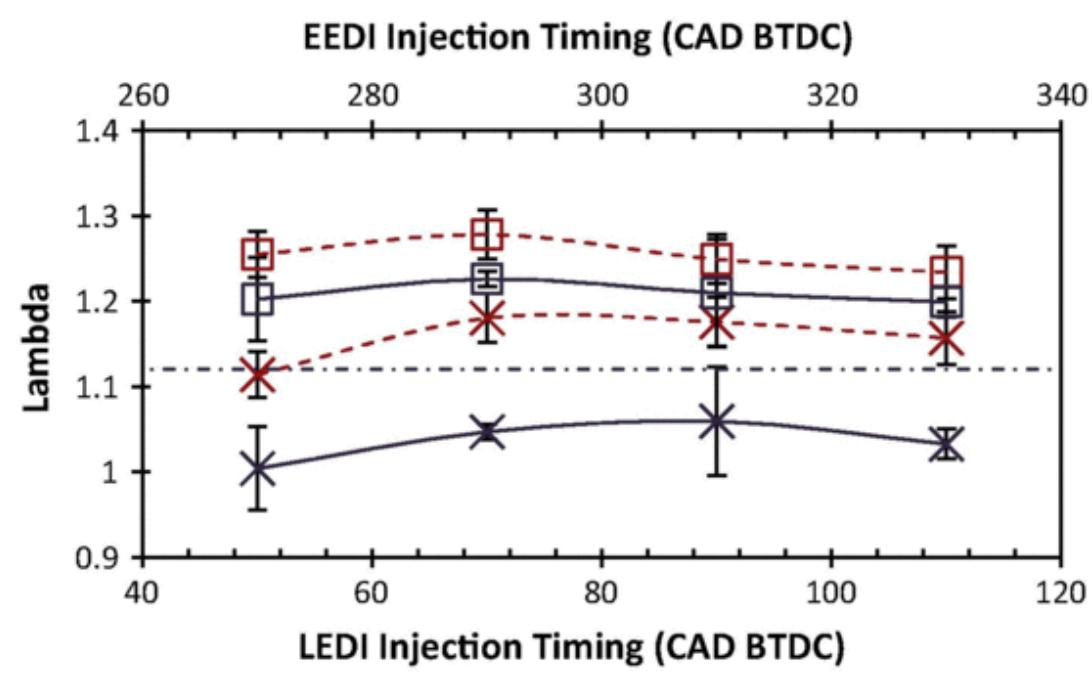

$$
\begin{aligned}
& \text { - - ×- - EER24\% LEDI — } \quad \text { EER48\% LEDI - - घ- - EER24\% EED } \\
& \square-\text { EER48\% EEDI - - - - . G GPI }
\end{aligned}
$$

Fig. 13 Variation of lean burn limit with SOI timing at EERs of $24 \%$ and $48 \%$. 


\section{ELSEVIER_JFUE_8212}

\section{EEDI Injection Timing (CAD BTDC)}

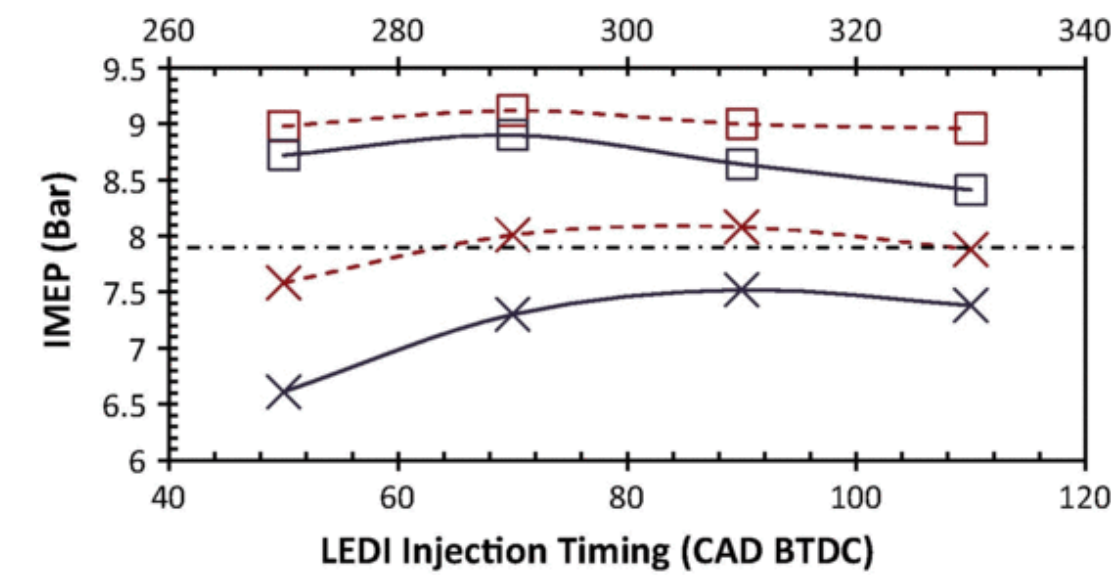

$$
\begin{array}{ll}
--\rtimes-- \text { EER24\% LEDI } & \star x \text { EER48\% LEDI - - }-- \text { EER24\% EEDI } \\
&
\end{array}
$$

Fig. 14 Variation of IMEP at lean burn limit.

EEDI Injection Timing (CAD BTDC)

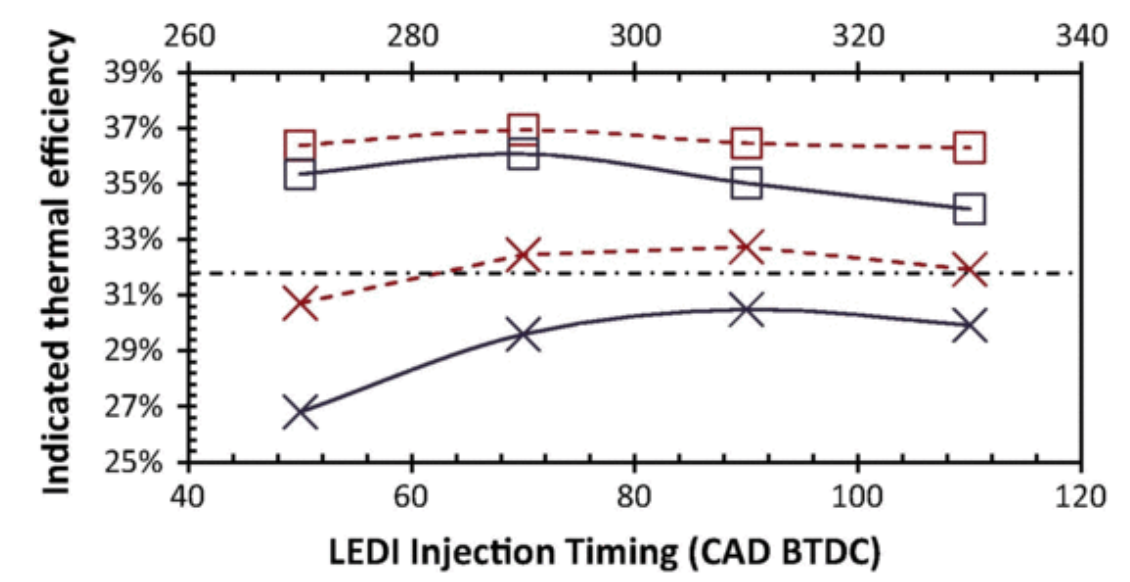

$$
\begin{array}{ll}
--\star x-- \text { EER24\% LEDI } & \ngtr \text { EER48\% LEDI } \\
\square-\text { EER48\% EEDI } & -\cdots \cdot-\cdot \text { GPI }
\end{array}
$$

Fig. 15 Variation of indicated thermal efficiency at lean burn limit.

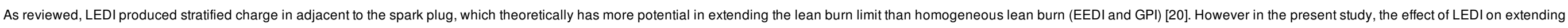

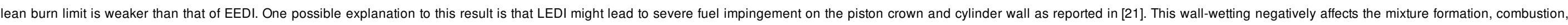

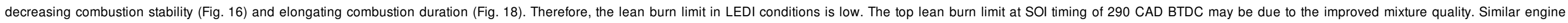
performance improvement at this SOI timing is also shown in Figs. 6 and 7 . 


\section{ELSEVIER_JFUE_8212}

EEDI Injection Timing (CAD BTDC)

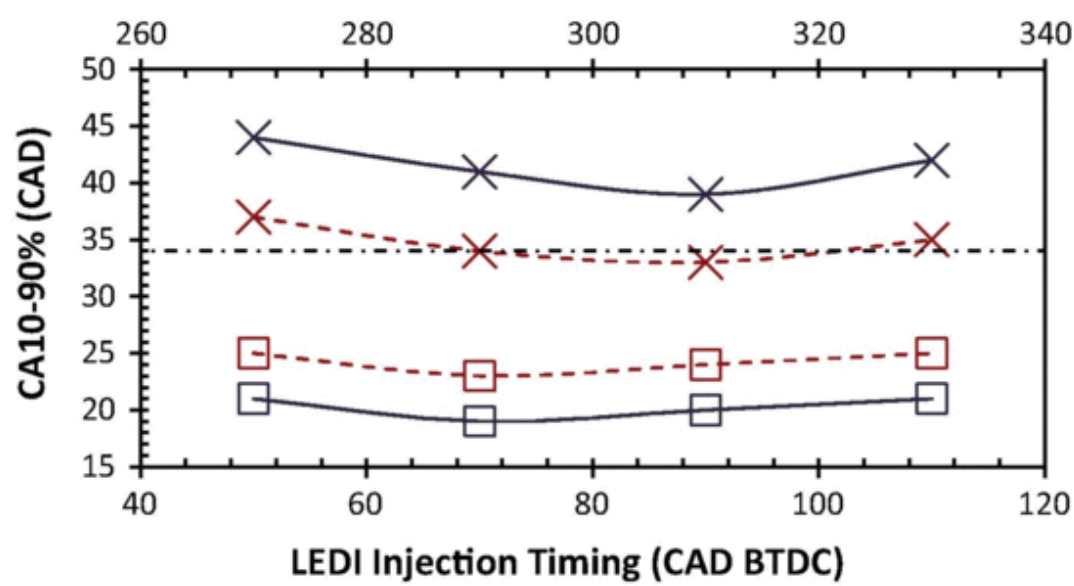

- - ×- - EER24\% LEDI — $\longrightarrow$ EER48\% LEDI - - - - EER24\% EEDI

口- EER48\% EEDI - - - - - . GPI

Fig. 18 Variation of $\mathrm{CA} 10-90 \%$ at lean burn limit.

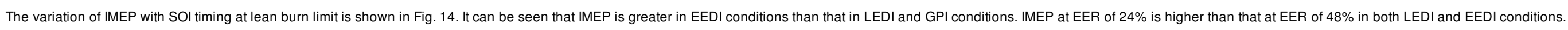

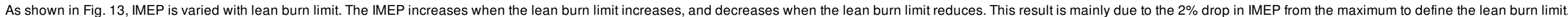

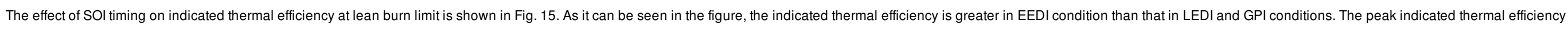

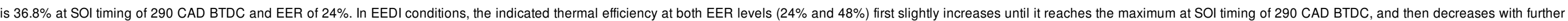
advance of SOI timing. In LEDI conditions, the indicated thermal efficiency first increases with the advance of SOI timing and then begins to decrease when the SOI timing is earlier than $90 \mathrm{CAD} B \mathrm{BTC}$.

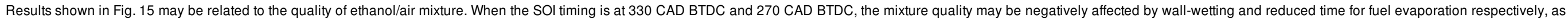

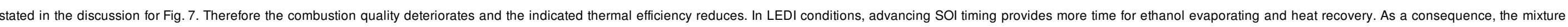
quality is improved and the in-cylinder temperature is increased. Thus the combustion is improved and indicated thermal efficiency is increased.

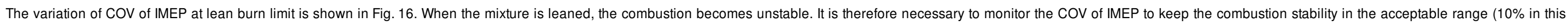

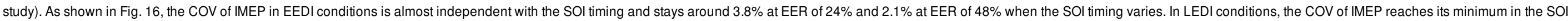

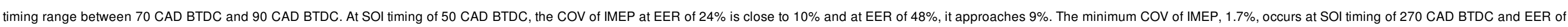
$48 \%$. COV of IMEP in GPI condition is 4.8\%, which is greater than that in EEDI conditions and lower than that in LEDI conditions.

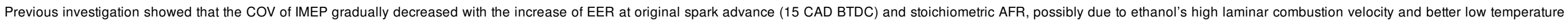

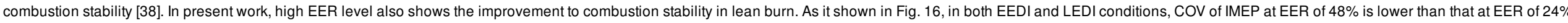

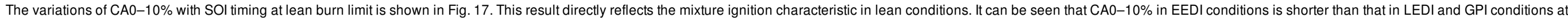

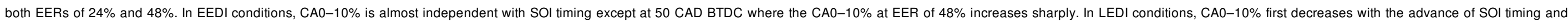

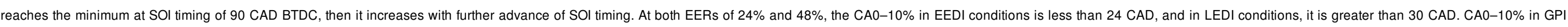
condition is 29 CAD which lies between that in EEDI and LEDI conditions.

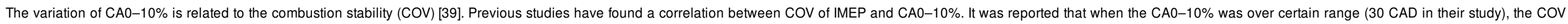

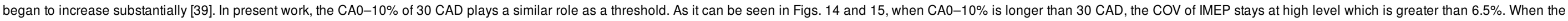




\section{ELSEVIER_JFUE_8212}

CA0-10\% is shorter than $30 \mathrm{CAD}$, the combustion stays stable and COV of IMEP is less than $4 \%$ (in EEDI conditions).

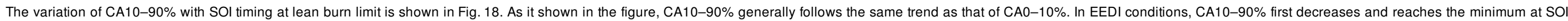

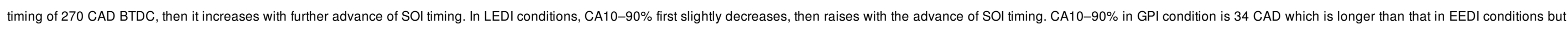

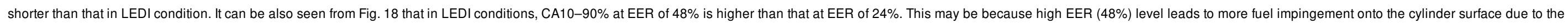
increased DI fuel amount, which ultimately prolongs the combustion duration.

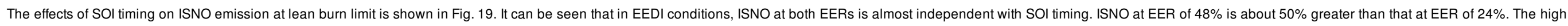

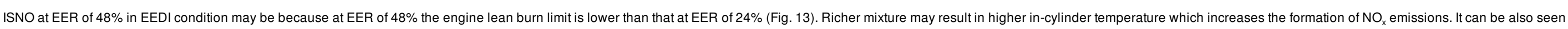

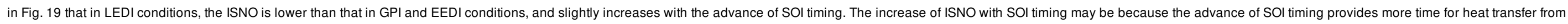
cylinder wall to fresh charge, which finally contributes to the increase of combustion temperature.

\section{EEDI Injection Timing (CAD BTDC)}

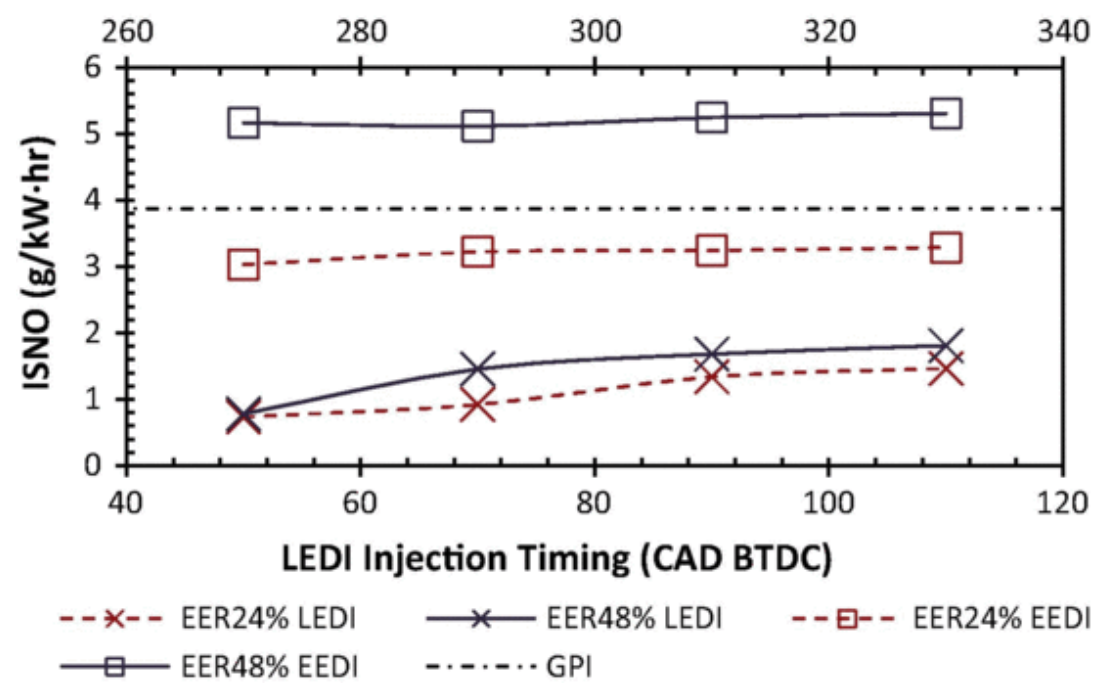

Fig. 19 Variation of ISNO at lean burn limit.

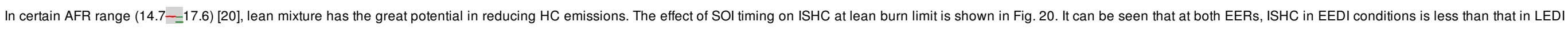

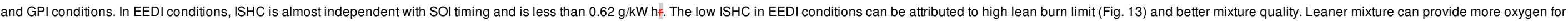

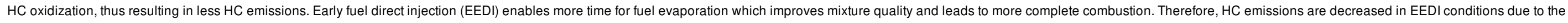

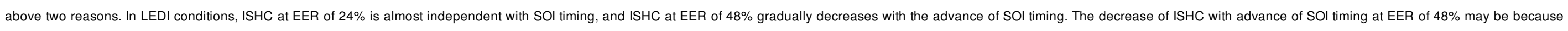
advancing SOl timing provides more time for improving mixture homogeneity. 


\section{ELSEVIER_JFUE_8212}

\section{EEDI Injection Timing (CAD BTDC)}

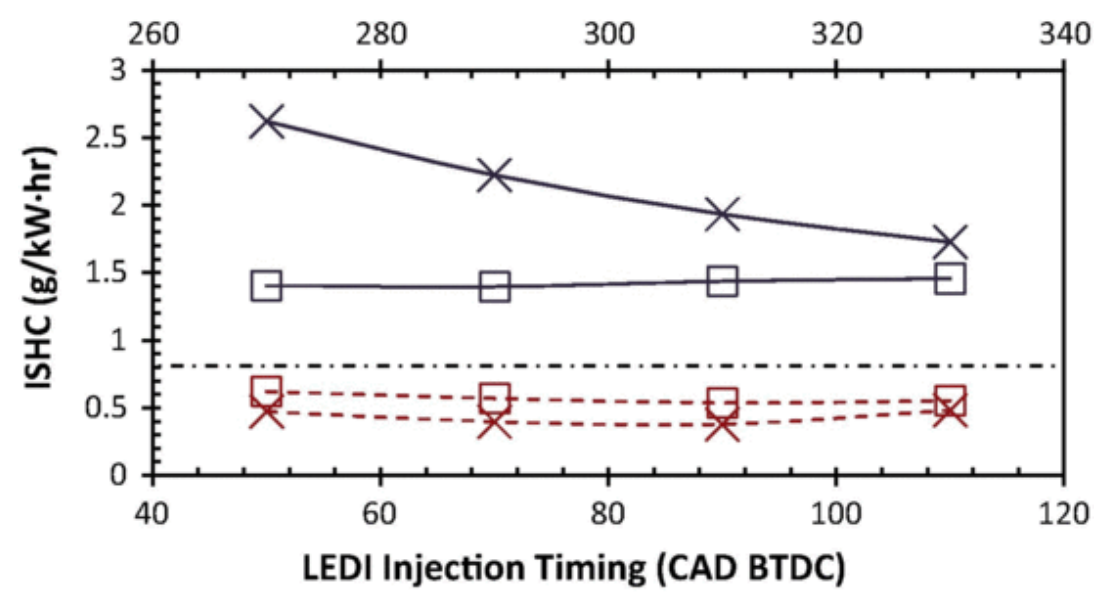

$$
\begin{aligned}
& \text { - - ×- - EER24\%LEDI — — EER48\%LEDI - - - - EER24\% EEDI } \\
& \text { —- EER48\% EEDI -...... GPI }
\end{aligned}
$$

Fig. 20 Variation of ISHC at lean burn limit.

\section{Conclusions}

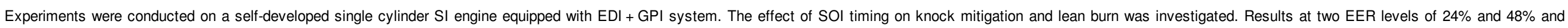
injection strategies of LEDI and EEDI were compared. Based on the analysis of experimental results, the following conclusions can be drawn.

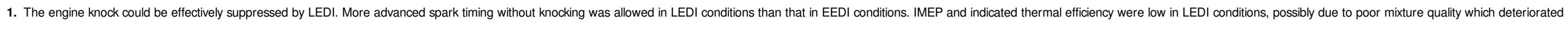
the combustion.

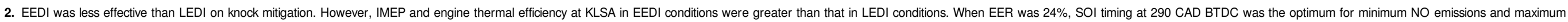
engine efficiency.

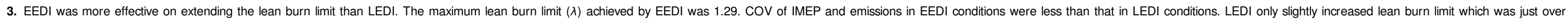

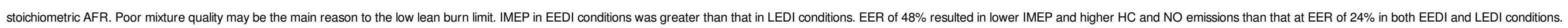

\section{Uncited references}

[28,29]

\section{Acknowledgments}

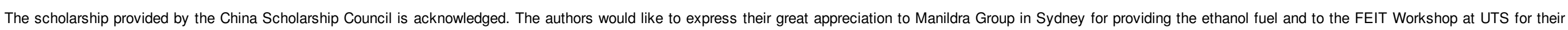
technical assistance and support.

\section{References}

[1]

T. Serra and D. Zilberman, Biofuel-related price transmission literature: a review, Energy Econom 2013. 


\section{ELSEVIER_JFUE_8212}

DIRECTIVE 2009/28/EC. DIRECTIVE 2009/28/EC Off J Eur Union; 2009.

[3]

US Ethanol Industry: the next inflection point. BCurtis Energies and Resource Group, 2007 year in review; 2008.

[4]

J. Goldemberg, The challenge of biofuels, Energy Environ Sci 1, 2008, 523-525.

[5]

B.Q. He, J.X. Wang, J.M. Hao, X.G. Yan and J.H. Xiao, A study on emission characteristics of an EFI engine with ethanol blended gasoline fuels, Atmos Environ 37, 2003, 949-957.

[6]

S.G. Poulopoulos, D.P. Samaras and C.J. Philippopoulos, Regulated and unregulated emissions from an internal combustion engine operating on ethanol-containing fuels, Atmos Environ 35, 2001, 4399-4406.

[7]

W.D. Hsieha, R.H. Chen, T.L. Wub and T.H. Lin, Engine performance and pollutant emission of an SI engine using ethanol-gasoline blended fuels, Atmos Environ 36, $2002,403-410$.

[8]

R.C. Costa and J.R. Sodré, Compression ratio effects on an ethanol/gasoline fuelled engine performance, Appl Thermal Eng 31 (2), 2011, $278-283$.

[9]

M.B. Celik, Experimental determination of suitable ethanol-gasoline blend rate at high compression ratio for gasoline engine, Appl Thermal Eng 28 (5), $2008,396-404$.

[10]

Pannone G, Johnson R. Methanol as a fuel for a lean turbocharged spark ignition engine. SAE Technical Paper 890435; 1989, http://dx.doi.org/10.4271/890435.

[11]

Germane G, Wood C, Hess C. Lean combustion in spark-ignited internal combustion engines - a review. SAE Technical Paper 831694; 1983 , http://dx.doi.org/10.4271/831694.

[12]

Ikoma T, Abe S, Sonoda Y. Development of V-6 3. 5-liter engine adopting new direct injection system; 2006.

[13]

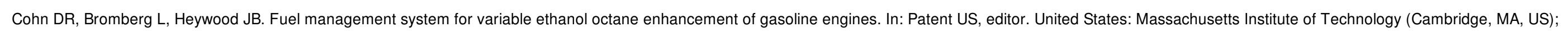
2010.

[14]

R.H. Chen, L. Chiang, C. Chen and T. Lin, Cold-start emissions of an SI engine using ethanol-gasoline blended fuel, Appl Thermal Eng 31, 2011, $1463-1467$.

[15]

D. Kabasin, K. Hoyer and J. Kazour, Heated injectors for ethanol cold starts, SAE 2, 2009, 172-179.

[16]

Stein RA, House CJ, Leone TG. Optimal use of E85 in a turbocharged direct injection engine. SAE 2009-01-1490.

[17]

R. Daniel, C. Wang, H. Xu and G. Tian, Dual-injection as a knock mitigation strategy using pure ethanol and methanol, SAE Int J Fuels Lubr 5 (2), 2012, 772-784, DOI: 10.4271/2012-01-1152. 


\section{ELSEVIER_JFUE_8212}

[18]

Cohn DR, Bromberg L, Heywood JB. Fuel management system for variable ethanol octane enhancement of gasoline engines. U.S. Patent 7,640,915,B2, June 5; 2010.

[19]

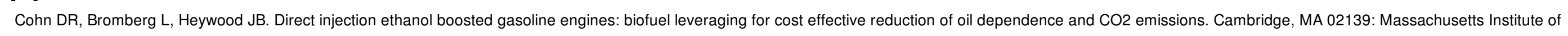
Technology; 2005.

[20]

Lean combustion: technology and control. Access Online via Elsevier; 2011.

[21]

Brehob D, Fleming J, Haghgooie M, Stein R. Stratified-charge engine fuel economy and emission characteristics. SAE Technical Paper 982704; 1998, http://dx.doi.org/10.4271/98270.

[22]

C. Ji and S. Wang, Effect of hydrogen addition on combustion and emissions performance of a spark ignition gasoline engine at lean conditions, Int J Hydrogen Energy 34 (18), $2009,7823-7834$.

\section{[23]}

M. Wei, Y. Wang and L. Reh, Experimental investigation of the prevaporized premixed (vpl) combustion process for liquid fuel lean combustion, Chem Eng Process: Process Intens 41 (2), $2002,157-164$.

\section{[24]}

Achleitner E, Bäcker H, Funaioli A. Direct injection systems for otto engines. SAE Technical Paper 2007-01-1416; 2007, http://dx.doi.org/10.4271/2007-01-1416.

[25]

S. Hemdal, I. Denbratt, P. Dahlander and J. Warnberg, Stratified cold start sprays of gasoline-ethanol blends, SAE Int J Fuels Lubr 2 (1), 2009, 683-696, DOI: 10.4271/2009-01-1496.

[26]

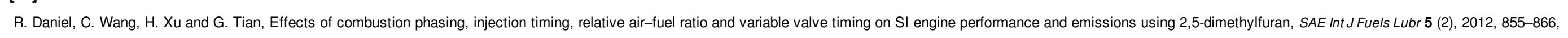

DOI: $10.4271 / 2012-01-1285$.

\section{[27]}

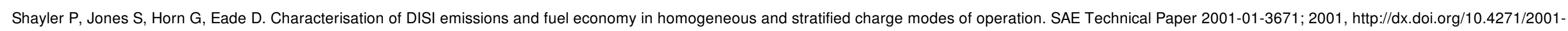
01-3671.

[28] YBR 250 Service Manual, 1sted., February 2007.

[29] Aaimone BA. Motoreycle automatic eluteh with manual release: U.S. Patent 6,533,056. 2003-3-18.

[30]

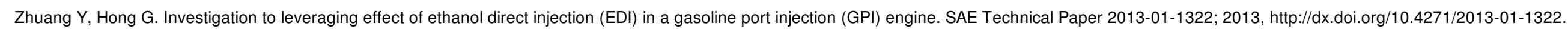

[31]

W. Chongming, R. Daniel and H.M. Xu, Combustion characteristics and emissions of 2-methylfuran compared to 2,5-dimethylfuran, gasoline and ethanol in a DISI engine, Fuel 103, 2013 , 200-211.

[32]

T. Albert and J. Karl Hedrick, A method of lean air-fuel ratio control using combustion pressure measurement, JSAE Rev 22 (4), 2001, 389-393.

[33]

J.S. Wijesinghe and G. Hong, Effect of spark assistance on autoignition combustion in a small two-stroke engine, Proc Inst Mech Eng Part D: J Automobile Eng 225 (1), $2011,115-126$. 


\section{ELSEVIER_JFUE_8212}

\section{[34]}

Yang J, Anderson R. Fuel injection strategies to increase full-load torque output of a direct-injection SI engine. SAE Technical Paper 980495; 1998 , http://dx.doi.org/10.4271/980495.

\section{[35]}

Szybist J, Foster M, Moore W, Confer K. Investigation of knock limited compression ratio of ethanol gasoline blends. SAE Technical Paper 2010-01-0619; 2010, http://dx.doi.org/10.4271/2010-01-0619.

\section{[36]}

R. Daniel, H.M. Xu, C. Wang, G. Tian and D. Richardson, Combustion performance of 2,5-dimethylfuran blends using dual-injection compared to direct-injection in a SI engine, Appl Energy 98, 2012, 59-68.

[37]

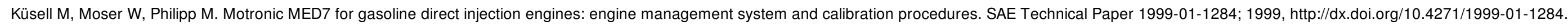

\section{[38]}

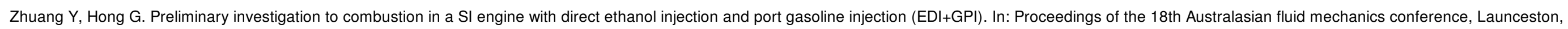
Australia, 3-7 December; 2012.

[39]

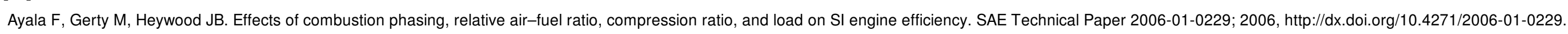

Highlights

- Ethanol direct injection + gasoline port injection was experimentally investigated.

- Late ethanol direct injection (LEDI) was effective on suppressing engine knock.

- Early ethanol direct injection (EEDI) resulted in higher efficiency than LEDI did.

- EEDI was more effective on extending the lean burn limit than LEDI was.

\section{Queries and Answers}

Query: Please confirm that given name(s) and surname(s) have been identified correctly.

Answer: The given names and surmanes of authors have been identified correctly.

Query: The country name has been inserted for affiliation. Please check, and correct if necessary.

Answer: The country name is correct.

Query: The number of keywords provided exceeds the maximum allowed by this journal. Please delete one keyword.

Answer: One of the keywords have been deleted

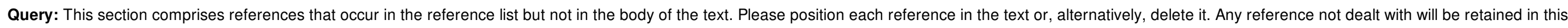
section.

Answer: Please delete references of 28 and 29, and revise reference number from 30-39. 